\title{
Appropriate Surgical Extent in the Surgery for Graves' Disease
}

\author{
Han Seok Yoo, Ki Yong Kim ${ }^{1}$, Yong Bae Ji ${ }^{1}$, Dong Sun Kim ${ }^{2}$, You Hern Ahn ${ }^{2}$ and Kyung Tae ${ }^{1}$ \\ ${ }^{1}$ Departments of Otolaryngology-Head and Neck Surgery, ${ }^{2}$ Endocrinology, College of Medicine, Hanyang University, Seoul, Korea
}

\section{그레이브스병의 수술에서 적절한 절제 범위}

유한석 ${ }^{1} \cdot$ 김기용 $^{1} \cdot$ 지용배 ${ }^{1} \cdot$ 김동선 $^{2} \cdot$ 안유헌 $^{2} \cdot$ 태 경 $^{1}$

한양대학교 의과대학 이비인후-두경부외과학교실, ${ }^{1}$ 내분비내과학교실 ${ }^{2}$

\author{
Received August 16, 2011 \\ Revised September 30, 2011 \\ Accepted October 4, 2011 \\ Address for correspondence \\ Kyung Tae, MD \\ Department of Otolaryngology- \\ Head and Neck Surgery, \\ College of Medicine, \\ Hanyang University, \\ 222 Wangsimni-ro, Seongdong-gu, \\ Seoul 133-791, Korea \\ Tel $+82-2-2293-8585$ \\ Fax $+82-2-2293-3335$ \\ E-mail kytae@hanyang.ac.kr
}

Background and Objectives Thyroidectomy for Graves' disease is a rapid, safe, highly successful treatment modality. Also thyroidectomy allows pathological examination for diagnosis of suspected cancer. However, the extent of thyroidectomy in Graves' disease is still controversial. The aim of this study is to evaluate the appropriate surgical extent by comparing the postoperative outcomes of two groups of patients with Graves' disease who underwent total or less than total thyroidectomy.

Subjects and Method We carried out a retrospective review of 33 patients who underwent thyroidectomy for Graves' disease from January 2001 to December 2010. We investigated the postoperative thyroid hormone function and complication rate according to the extent of thyroidectomy.

Results Among the 33 patients with Graves' disease, 19 patients underwent total thyroidectomy, six patients bilateral subtotal thyroidectomy (BST) and eight patients lobectomy and contralateral subtotal lobectomy (LCSL). Postoperative hypothyroidism, euthyroidism, and hyperthyroidism occurred in $27(81.7 \%), 2(6.1 \%)$ and $4(12.2 \%)$ patients, respectively. Postoperative recurrent hyperthyroidism was observed in $2(33.3 \%)$ patients of BST and in 2 $(25.0 \%)$ of LCSL. One patient was found with permanent hypoparathyroidism, and two with transient vocal cord paralysis. According to histopathologic report, nine patients were accompanied with thyroid cancer.

Conclusion Thyroidectomy for Graves' disease has high success rate, low recurrence rate and low complication rate. In terms of surgical extent, total thyroidectomy is a more appropriate procedure because of its low recurrence of hyperthyroidism.

Korean J Otorhinolaryngol-Head Neck Surg 2011;54:771-7

Key Words Graves' disease · Thyroidectomy · Hyperthyroidism.

\section{서 론}

그레이브스병은 갑상선기능항진증의 가장 흔한 원인 질환 으로, 갑상선자극호르몬 수용체 항체(thyroid-stimulating hormone-receptor antibodies)가 갑상선자극호르몬 수용체 를 자극하여 여러 증상이 나타나는 자가면역질환이다. ${ }^{1)}$ 그레 이브스병의 치료목표는 갑상선 호르몬의 과분비를 억제시켜
임상 증상을 빠르게 호전시키고, 재발을 방지하며, 치료 후 정 상 갑상선 기능 상태로 유지하는 것이나, 현재 이러한 목표를 모두 충족시키는 것은 어려운 것으로 알려져 있다. ${ }^{2)}$

그레이브스병의 치료는 항갑상선제 등을 이용한 약물 요법, 방사성 동위원소 치료, 수술적 치료 방법이 있다. 약물 요법의 장점은 복용이 간편하며, 빠른 효과를 기대할 수 있고, 임신 중 이나 수유 중에 사용할 수 있으며 안구합병증의 악화를 유발 
하지 않는다는 것이다. ${ }^{3)}$ 하지만 단점으로 발열이나 발진, 간 독성 등을 유발하며, 특히 과립백혈구 감소증과 같은 치명적 인 부작용이 발생할 수 있다. ${ }^{4)}$ 또한 증상 완화를 위한 약물 요 법의 기간과 약물의 용량을 결정하기 어렵고, 일시적으로 호전 되더라도 많은 경우 증상이 재발되며 ${ }^{3)}$ 약 $15 \%$ 의 환자에서는 갑상선 기능 저하증이 유발될 수 있다는 단점이 있다.3) 방사성 동위원소 치료는 방법이 간편하고, 가격이 싸다는 장점이 있으 나, 초 치료시 용량 결정이 어렵고, 치료 후 대부분의 경우 갑 상선 기능 저하를 초래하며,5) 임신 중이나 수유 중에는 사용 할 수 없으며, 갑상선 종대가 심한 경우에는 적절치 못하다는 단점이 있다. ${ }^{3)}$ 또한 치료 시작 후 효과가 나타날 때까지의 시 간이 약 6주에서 6개월까지로 치료 효과가 즉각적이지 않고, 증상의 재발이 많아 반복적 치료가 필요하며 그레이브스병의 안구합병증을 악화시킬 수 있는 가능성도 제기되고 있다. ${ }^{3)}$ 한국과 일본, 유럽 등에서는 약물 요법이 선호되고, 미국 등 에서는 방사성 동위원소 치료가 선호되어, 수술적 치료가 일 차적으로 시행되는 경우는 많지 않으나, 우수룰은 빠르고 효과 적으로 갑상선 호르몬의 과분비를 억제시킬 수 있다. ${ }^{7)}$ 또한 수술적 치료의 적응증은 주로 약물 요법이나 방사성 동위원 소의 치료가 실패하거나 증상이 재발한 경우, 갑상선 선종의 크기가 매우 큰 경우, 암종이 의심되는 갑상선 결절이 동반된 경우, 환자의 나이가 어리거나 젊은 가임기 여성인 경우, 기관 식도를 압박하는 증상이 있을 경우, 그 외 빠른 치료를 원하거 나 순응도가 낮은 환자의 경우이다. 한편 그레이브스병의 수 술 방법에는 갑상선 아전절제술, 전절제술 등이 있는데, 술 후 정상 갑상선 기능을 유지하기 위한 적절한 갑상선 절제술의 범위에 대하여 아직까지도 논란이 있다.8)

이에 저자들은 그레이브스병으로 수술 받은 33예를 대상 으로 갑상선 절제술의 범위에 따른 술 후 갑상선 기능의 변 화 양상과 술 후 합병증 사이의 상관관계를 분석하여, 그레 이브스병에서 갑상선 절제술의 안정성과 적절한 수술 범위의 결정에 도움을 얻고자 본 연구를 시행하였다.

\section{대상 및 방법}

2001년 1월부터 2010년 12월까지 한양대학교병원 이비인 후-두경부외과에서 그레이브스병으로 갑상선 절제술을 시 행받은 33명의 환자를 대상으로 후향적 연구를 시행하였다. 환자의 평균 연령은 36.4 \pm 14.54 세(14 77)였고, 여성이 28예 (84.8\%), 남성이 5예(15.2\%)였다. 대상군의 술 후 추적 관찰 기간은 7개월에서 63개월까지였으며 평균 26개월이었다.

그레이브스병의 증상 및 징후, 수술 적응증, 수술 전 처치 방법 등을 조사하였고, 그레이브스병에서의 적절한 수술적
절제 범위를 알고자 절제 범위에 따른 수술 전후의 갑상선 호르몬 기능 변화, 갑상선 자가 면역 항체의 변화와 술 후 합 병증 등을 분석하였다.

수술 적응증으로는 약물 요법에 반응이 없거나 재발된 경우 가 16예(48.5\%)로 가장 많았고, 심한 갑상선 종대로 인하여 미 용적 또는 기능상 문제가 발생한 경우가 9예(27.3\%), 세침흡 인 세포검사 상 갑상선 암이 의심되었던 경우가 8예(27.3\%) 였다.

술 전 처치로 정상 갑상선 기능을 유지하기 위해 항갑상선 제를 복용하였으며, 심계항진이 동반된 경우에는 $\beta$-adrenergic 수용체 길항제를 같이 복용하였다. 갑상선 종대가 심하 여 수술 중에 출혈이 우려되는 경우에는 수술 전 10 일간 Lugol 용액을 복용하였다.

갑상선 절제술로는 갑상선 전절제술, 양측 갑상선 아전절제 술, 일측엽 전절제술 및 반대측엽 아전절제술의 3 가지 술식 을 시행하였는데, 양측 갑상선 아전절제술은 양측엽에서 각각 갑상선 조직 2 3 gm을 남겨놓는 술식이며, 일측엽 전절제술 및 반대측엽 아전절제술은 일측엽은 전절제하고 반대측에서 갑상선 조직 3 6gm 정도를 남기는 술식이다. 수술시 남기는 갑 상선 잔여량은 절제된 갑상선 조직에서 잔여 갑상선과 비슷 한 크기로 잘라 무게를 측정하여 결정하였다.

일시적 부갑상선 기능 저하증은 갑상선 절제술 후 저칼슘 혈증 증상의 발현과 상관 없이 부갑상선 호르몬의 저하가 술 후 6개월 이내에 호전되는 경우로 정의하였고, 영구적 부갑 상선 기능 저하증은 술 후 6 개월 이후까지 부갑상선 호르몬의 저하가 지속되는 경우로 하였다. 수술 전후 후두 내시경을 통 해 성대의 움직임을 관찰하여 반회후두신경의 손상 여부를 관찰하였다. 술 후 6개월 이내에 호전된 성대 마비를 일시적 마비, 6개월 이후까지 지속되는 경우를 영구적 성대 마비로 정 의하였다. 술 후 혈종, 감염 등의 발생 여부도 조사하였다.

술 후 갑상선 호르몬 기능에 영향을 미치는 관련 인자를 알 아보고자, 수술 범위, Thyroid Stimulating Immunoglobulin (TSI), Anti-thyroglobulin antibody(Anti-Tg Ab), Anti-thyroid peroxidase antibody(Anti-TPO Ab) 등의 immunoglobulin, 갑상선 조직 내 림프구 침윤에 따른 술 후 갑상선 기능과의 관계를 분석하였다. 갑상선 조직 내 림프구 침윤 정도는 40 배 율 시야에서 림프구가 전혀 없거나 거의 없는 경우를 0 등급, 여포 형성 없이 림프구가 산재해 있는 경우를 I등급, 1 2개의 소포가 관찰되면 II등급, 3 개 이상의 소포형성은 III등급으로 정하고, 배중심이 있는 경우를 IV등급으로 나누었다.

통계 분석으로는 갑상선 절제 범위에 따른 술 후 갑상선 호르몬 기능 변화의 관련성을 알아보기 위해 Analysis of variance (ANOVA) test로 검정하였고, TSI, Anti-Tg Ab, Anti- 
$\mathrm{TPO} \mathrm{Ab}$ 등의 immunoglobulin, 갑상선 조직내 림프구 침윤 정도와 술 후 갑상선 호르몬 기능과의 관련성을 알아보기 위 해 Chi-square test로 검정하였다. 통계학적 유의 수준은 95\% 이상 $(p$-value $<0.05)$ 으로 하였다.

\section{결 과}

\section{그레이브스병의 증상 및 징후}

환자들이 호소하는 증상으로는 경부 종물(goiter)이 29예 (87.9\%)로 가장 많았으며, 심계항진 20예(60.6\%), 체중감소 11예(33.3\%), 쇠약감 11예(33.3\%) 등의 순으로 나타났고, 안구 병증은 5예(15.2\%)에서 호소하였다(Table 1).

\section{수술 전 갑상선 호르몬 기능 검사 및 갑상선 스캔 검사}

수술 직전 측정한 free T4는 10예(30.3\%)에서 정상보다 높 았고, 15예(45.5\%)에서 정상, 8예(24.2\%)에서 정상보다 낮았다. $\mathrm{TSH}$ 는 7예(21.2\%)에서 정상보다 낮았고, 21예(63.6\%)에서 정상, 5예(15.2\%)에서 정상보다 높았다. T3는 24예에서 검사 를 시행하였고, 6예(25.0\%)에서 정상보다 높았고, 11예(45.8\%) 에서 정상, 7예(29.2\%)에서 정상보다 낮았다. Thyroglobulin antigen은 8예에서 검사를 시행하였으며, 6예(75.0\%)에서 정 상보다 높았고, 2예(25.0\%)에서 정상이었고, 정상보다 낮았

Table 1. Symptoms and signs of Graves' disease

\begin{tabular}{lc}
\hline Symptoms and signs & Number of patients $(\mathrm{n}=33)(\%)$ \\
\hline Opthalmopathy & $5(15.2)$ \\
Goiter & $29(87.9)$ \\
Palpitation & $20(60.6)$ \\
Weight loss & $11(33.3)$ \\
Weakness and fatigue & $11(33.3)$ \\
Heat intolerance & $10(30.3)$ \\
Tremor & $9(27.3)$ \\
Dyspnea & $5(15.2)$ \\
Edema & $3(9.1)$ \\
Irregular menstruation & $3(9.1)$ \\
Headache & $3(9.1)$ \\
Nervousness & $2(6.1)$ \\
Nausea \& vomiting & $2(6.1)$ \\
\hline
\end{tabular}

던 경우는 없었다. TSI는 19예에서 검사를 시행하였으며, 17 예(89.5\%)에서 정상보다 높았고, 2예(10.5\%)에서 정상이었다 (Table 2). Anti-Tg Ab는 19예에서 시행하였으며, 8예(44.4\%) 는 양성, 10예(55.6\%)는 음성이었다. Anti-TPO Ab는 1예에서 시행하였으며 양성이었다. 갑상선 스캔 검사는 17 예에서 시행 하였으며 17예(100\%)에서 모두 섭취 증가가 보였고, 2예(11.8\%) 에서 냉결절 소견이 관찰되었다.

술 전 검사 상 항진증 상태를 보였던 30.3\%(10/33)는 수술받 기 수개월 전부터 항갑상선제를 복용하였음에도 호르몬 수 치가 정상화되지 않았다.

\section{술 전 처치 및 수술 방법}

총 33예의 환자 중 30예(90.9\%)는 이전에 항갑상선제를 복 용한 경력이 있었다. 그 중 14 예는 수술 1 개월 전부터 16 개월 전 사이에 약 복용을 중단하였고, 10 예의 환자는 수술 직전 까지 항갑상선제를 지속적으로 복용하였으며, 나머지 6예는 수년 전 항갑상선제를 중지하였으나, 이후 갑상선 기능 항진이 재발되어 수술 직전까지 항갑상선제를 다시 복용하였다.

술 전 갑상선 호르몬 기능 검사 상 10예(30.3\%)에서 갑상선 기능 항진 상태, 15 예(45.5\%)에서 정상 기능, 8 예(24.2\%)에서 갑상선 기능 저하 상태를 보였다. 심계항진 등의 심혈관계 증 상이 동반되었던 16예(48.5\%)에서는 항갑상선제와 더불어 $ß$-adrenergic 수용체 길항제를 복용하였다. 18예(48.5\%)에서 는 수술 중 출혈을 줄이기 위하여 수술 10 일 전부터 Lugol 용 액을 복용하였다.

술식으로는 갑상선 전절제술이 19예(57.6\%)로 가장 많이 시 행되었고, 양측 갑상선 아전절제술은 6예(18.2\%), 일측엽 전절 제술 및 반대측엽 아전절제술은 8예(24.2\%)에서 시행되었다 (Table 3). 수술로 제거된 갑상선의 무게는 $40 \mathrm{gm}$ 에서 $523 \mathrm{gm}$

Table 3. Extent of thyroidectomy in Graves' disease

\begin{tabular}{lc}
\hline \multicolumn{1}{c}{ Extent of operations } & Number of patients (\%) \\
\hline Total thyroidectomy & $19(57.6)$ \\
Bilateral subtotal thyroidectomy & $6(18.2)$ \\
Lobectomy with contralateral & $8(24.2)$ \\
$\quad$ subtotal lobectomy & $33(100)$ \\
\hline Total &
\end{tabular}

Table 2. Preoperative thyroid function test (fT4, TSH, T3, Tg, TSI)

\begin{tabular}{|c|c|c|c|c|c|}
\hline & \multicolumn{5}{|c|}{ Number of patients (\%) } \\
\hline & $\begin{array}{l}\text { fT4 }(n=33) \\
(0.93-1.7)\end{array}$ & $\begin{array}{c}\text { TSH }(n=33) \\
(0.27-4.2)\end{array}$ & $\begin{array}{l}\text { T3 }(n=24) \\
(80-200)\end{array}$ & $\begin{array}{l}\operatorname{Tg}(n=8) \\
(1.4-78)\end{array}$ & $\begin{array}{c}\text { TSI }(n=19) \\
(0-1.5)\end{array}$ \\
\hline High & $10(30.3)$ & $5(15.2)$ & $6(25.0)$ & $6(75.0)$ & $17(89.5)$ \\
\hline Normal & $15(45.6)$ & $21(63.6)$ & $11(45.8)$ & $2(25.0)$ & $2(10.5)$ \\
\hline Low & $8(24.2)$ & $7(21.2)$ & $7(29.2)$ & $0(0.0)$ & $0(0.0)$ \\
\hline
\end{tabular}

fT4: free thyroxine, TSH: thyroid-stimulating hormone, T3: triiodothyronine, Tg: thyroglobulin, TSI: thyroid stimulating immunoglobulin 
으로 평균 $138 \mathrm{gm}$ 이었다.

\section{술 후 갑상선 기능 변화에 영향을 미치는 관련 인자}

\section{수술 범위와 술 후 갑상선 호르몬 기능과의 관계}

갑상선 전절제술을 시행한 19예 중 19예(100.0\%) 모두 기능 저하가 유발되었다. 양측 갑상선 아전절제술을 시행한 6 예 중 2예(33.3\%)에서 술 후 갑상선 기능 저하, 2예(33.3\%)에서 정상 갑상선 기능, 2예(33.3\%)에서 기능 항진이 재발되었다. 일측엽 전절제술 및 반대측엽 아전절제술을 시행한 8예 중 6예(75.0\%) 에서 기능 저하, 2예(25.0\%)에서 기능 항진이 재발되었다(Table 4). 갑상선 전절제술과 갑상선 부분 절제술 후 갑상선 기능 검 사 상, 정상 갑상선 기능이 유지되는 비율은 통계적으로 의미 가 있는 차이가 없었으나 $(p$-value $=0.172)$, 갑상선 부분 절제 술시 유의하게 전절제술에 비해 갑상선 기능 항진의 재발이 많았다 $(p-v a l u e=0.024)$. 갑상선 부분절제술 후 갑상선 기능 저하가 유발된 8예 중 3예는 술 후 1 3개월까지는 정상 갑상 선 기능을 유지하다가 이후 갑상선 기능 저하가 유발되었고, 나 머지 5예는 수술 직후부터 갑상선 기능 저하가 유발되었다.

\section{림프구 침윤 정도와 술 후 갑상선 기능과의 관계}

림프구 침윤 정도 0, I, II, III, IV등급에서 각각 18예(51.5\%), 4예(12.1\%), 1예(3.0\%), 3예(9.1\%), 1예(3.0\%)의 술 후 기능 저하
가 발생하였고, 0 등급에서 4 예(12.1\%)가 재발하였으나 통계 적 유의성은 없었다(Table 5).

\section{술 후 TSI, Anti Tg Ab의 변화 양상 및 술 후 갑상선 기능과의 관계}

술 전 검사상 TSI가 정상보다 높았던 17예 중 11예는 술 후 6 개월 이후에도 정상보다 높았고, 3예에서는 정상으로 되었 다. 술 후 6개월 이후까지 TSI 수치가 높게 측정된 11예 중 3 예에서 갑상선 기능 항진증이 재발하였다. TSI가 정상 범위에 속했던 2예 중 1 예는 술 후 6 개월 이후에도 정상이었으며, 갑 상선 기능 항진증이 재발한 경우는 없었다. 술 전 검사상 Anti$\mathrm{Tg} \mathrm{Ab}$ 가 양성이었던 8예 중 4예는 술 후에도 양성으로 나타 났고, 갑상선 기능 항진증이 재발한 경우는 없었다. 술 전 검 사 상 Anti-Tg Ab가 음성이었던 10예 중 3예는 술 후에도 음 성으로 관찰되었고 갑상선 기능 항진증이 재발한 경우는 없었 다. Chi-square 검사상 TSI, Anti-Tg Ab와 술 후 갑상선 호르 몬 기능과의 관계는 통계적으로 유의성이 없었다.

\section{갑상선 절제술의 범위와 술 후 합병증 유발과의 관계}

양측 갑상선 아전절제술, 일측엽 절제술 및 반대측엽 아전 절제술을 시행받은 환자들에서 모두 일시적 저칼슘 혈증이 유 발되었고, 갑상선 전절제술을 시행받은 환자 중 1 예(5.3\%)에 서 영구적 저칼슘 혈증이 유발되었다. 세 수술군 사이에서 술

Table 4. Association of postoperative thyroid function with extent of thyroidectomy in Graves' disease

\begin{tabular}{lccc}
\hline \multicolumn{1}{c}{ Extent of operations } & Hypothyroidism (\%) & Euthyroidism (\%) & Hyperthyroidism (\%) \\
\hline Total thyroidectomy & $19(100.0)$ & $0(0.0)$ & $0(0.0)$ \\
Bilateral subtotal thyroidectomy & $2(33.3)$ & $2(33.3)$ & $2(33.3)$ \\
Lobectomy with contralateral subtotal lobectomy & $6(75.0)$ & $0(0.0)$ & $2(25.0)$ \\
\hline Total & $27(81.7)$ & $2(6.1)$ & $4(12.2)$ \\
\hline
\end{tabular}

Table 5. Postoperative thyroid function according to lymphocytic infiltration

\begin{tabular}{|c|c|c|c|c|c|}
\hline & \multicolumn{5}{|c|}{ Degree of lymphocytic infiltration } \\
\hline & 0 & 1 & $\|$ & III & IV \\
\hline Hypothyroidism & $17(51.5)$ & $4(12.1)$ & $1(3.0)$ & $3(9.1)$ & $1(3.0)$ \\
\hline Euthyroidism & $1(3.0)$ & $1(3.0)$ & $1(3.0)$ & $0(0.0)$ & $0(0.0)$ \\
\hline Hyperthyroidism & $4(12.1)$ & $0(0.0)$ & $0(0.0)$ & $0(0.0)$ & $0(0.0)$ \\
\hline Total & $22(66.7)$ & $5(15.1)$ & $2(6.1)$ & $3(9.1)$ & $1(3.0)$ \\
\hline
\end{tabular}

p-value $>0.05$

Table 6. Complication of thyroidectomy in Graves' disease

\begin{tabular}{lccc}
\hline \multicolumn{1}{c}{ Complication } & $\begin{array}{c}\text { Total thyroidectomy }(\%) \\
(\mathrm{n}=19)\end{array}$ & $\begin{array}{c}\text { Bilateral subtotal } \\
\text { thyroidectomy }(\%)(\mathrm{n}=6)\end{array}$ & $\begin{array}{c}\text { Lobectomy with contralateral } \\
\text { subtotal lobectomy }(\%)(\mathrm{n}=8)\end{array}$ \\
\hline Transient hypocalcemia & $15(78.9)$ & $10(100.0)$ & $4(100.0)$ \\
Permanent hypocalcemia & $1(5.3)$ & $0(0.0)$ & $0(0.0)$ \\
Transient vocal palsy & $2(10.5)$ & $0(0.0)$ & $0(0.0)$ \\
Permanent vocal palsy & $0(0.0)$ & $0(0.0)$ & $0(0.0)$ \\
Hematoma & $0(0.0)$ & $1(10.0)$ & $1(25.0)$ \\
\hline
\end{tabular}


후 저칼슘 혈증의 유발률은 통계적으로 유의한 차이는 없었 다(Table 6).

양측 갑상선 아전절제술, 일측엽 절제술 및 반대측엽 아전 절제술을 시행받은 환자들에서는 성대마비가 발생하지 않았 다. 갑상선 전절제술을 시행받은 환자 중 2예(10.5\%)에서만 일시적 성대마비가 발생하였고, 영구적 성대마비는 발생하지 않았다. 세 수술군 사이에서 술 후 성대 마비의 유발률은 통 계적으로 유의한 차이는 없었다(Table 6).

양측 갑상선 아전절제술을 시행받은 환자 중 1예(10.0\%), 일 측엽 절제술 및 반대측엽 아전절제술을 시행받은 환자 중 1 예(25.0\%)에서 각각 술 후 출혈이 유발되었고, 갑상선 전절제 술을 시행받은 환자에서는 술 후 출혈이 발생되지 않았다. 술 후 창상 감염이 발생한 경우는 없었다(Table 6).

\section{조직학적 소견}

병리 조직 검사상 모든 예에서 미만성 갑상선 증식증 소견 이 관찰되었고, 하시모토 갑상선염이 동반된 경우는 3예(9.1\%), 선형 증식증이 동반된 경우는 2예(6.1\%), 갑상선 암이 동반된 경우는 9예(27.3\%)로 나타났다. 이 중 갑상선 유두상 암이 동 반된 경우가 8예(24.2\%), 여포상 암이 동반된 경우가 1예(3.0\%) 였다.

\section{고 찰}

그레이브스병의 수술적 치료는 현재 제한적으로 시행되고 있으나 많은 이점을 가지고 있다. 첫째, 갑상선 절제를 통해 효과적으로 호르몬의 과분비를 억제하여 3 9주 이내에 빠른 치료 효과가 나타난다.) 반면, 약물 요법은 최소 6 12개월의 치료가 지속되어야 효과가 나타나며, 방사성 동위원소 치료 역시 치료 효과가 나타나기까지 수 개월의 시간이 걸린다. 둘 째, 수술 전 처치 및 술기의 발달로 합병증의 유발률이 많이 낮아져 매우 안전한 치료 방법이다. 갑상선 절제술 후 발생할 수 있는 합병증에 대한 연구들에 따르면 술 후 일시적 저칼슘 혈증의 발생률이 6 20\%, 영구적 저칼슘 혈증이 0 3\%, 반회후 두신경 손상이 약 $0 \sim 1 \%$ 에서 발생한다고 보고되었다.9.10) 본 연 구 결과에서도 일시적 성대마비, 술 후 출혈은 각각 2예(6.1\%) 에서 나타났으며, 창상 감염은 없었기 때문에 수술적 치료는 매우 안전하다고 할 수 있다. 셋째, 갑상선 절제술은 그레이브 스병의 치료에 있어서 높은 성공률을 가진다. 연구에 따라 수 술 후 갑상선 기능 항진증의 재발률은 0.7 9.8\%까지 다양하게 보고되고 있지만,11,12) 약물 요법이나, 방사성 동위원소 치료에 비하여 재발률이 낮은 것으로 알려져 있다. ${ }^{13)}$ 본 연구 결과에 서는 갑상선 부분 절제술을 시행한 4 예에서만 갑상선 기능 항
진증이 재발되었고, 전절제술을 시행한 경우 19예 모두 갑상 선 기능 저하증이 나타났고, 갑상선 기능 항진증의 재발은 없 었다. 이처럼 그레이브스병에 있어서 갑상선절제술은 성공률 이 매우 높은 효과적인 술식이라고 할 수 있다. 넷째, 수술을 통해 조직학적인 진단이 가능하다. 그레이브스병으로 진단된 환자 중 15 20\%에서 갑상선 결절이 동반되며, ${ }^{14)}$ 그레이브스 병에서 냉결절이 동반된 경우 약 $45.8 \%$ 에서 갑상선암이 동반 된다고 알려져 있다.14) 또한 여러 연구들에 따르면 그레이브스 병에서 추적검사나 임상적으로 결절이 의심되지 않았던 경우 라도, 수술적 치료 후 우연히 갑상선암이 발견되는 경우가 2.1 $5 \%$ 정도라고 보고되고 있다. ${ }^{15,16)}$ 본 연구에서는 27.3\%(9/33) 에서 초음파상 갑상선암이 의심되어 술 전 세침 흡인 검사를 하여 갑상선암이 발견이 되어서 갑상선 전절제술을 시행하였 고, 술 후 조직검사상 우연히 갑상선암이 진단되었던 경우는 없었다. 그러므로 술 전 검사상 갑상선암이 의심되는 경우나 임상적으로 결절이 의심되지 않았던 경우라도, 암의 유발 방 지 및 조기 치료의 측면에서 갑상선 절제술이 보다 적절한 치 료 방법이 될 것으로 사료된다. 다섯째, 안구합병증이 동반된 그레이브스병의 경우 수술적 치료를 통해 안구합병증의 악 화를 방지할 수 있다. 약물요법이나 방사성 동위원소 치료의 경우, 치료로 인하여 갑상선 조직이 손상되어 갑상선 항체의 분비가 증가되고, 안구에서 항체에 대한 자가 면역 반응이 증 가되어, ${ }^{15)}$ 안구합병증이 악화될 수 있다. 또한 안구합병증이 동반된 그레이브스병에서는 자가 면역 반응이 증가되어, 기 능 항진증이 재발될 확률이 더 높다고 알려져 있다. ${ }^{17)}$ 하지 만 수술적 치료는 갑상선 절제술을 통해 갑상선 항체 분비의 증가를 억제할 뿐 아니라, 기능 항진증의 재발을 방지하는 데 유리하기 때문에, 안구합병증이 동반된 그레이브스병의 경우에는 갑상선 절제술이 일차적 치료로 알려져 있다. ${ }^{18)}$

이러한 여러 장점에도 불구하고 수술적 치료는 아직까지 많 은 단점이 있다. 첫째, 안전하게 수술을 시행하기 위해 수술 시 행 수 개월 전부터 세심한 수술 전 처치가 필요하다. 둘째, 수 술 전 처치 및 술기의 발달로 합병증의 유발률이 많이 낮아 지긴 하였지만 많은 경우 술 후 반회후두신경의 손상으로 인 한 성대 마비, 부갑상선 손상으로 인한 저칼슘혈증, 술 후 경 부에 남는 상처 등의 합병증의 가능성이 여전히 남아있다. 셋 째, 수술적 치료는 약물 요법이나 방사성 동위 원소 치료에 비 하여 높은 비용이 든다는 점도 단점으로 지적되고 있다. 넷째, 갑상선 전절제술을 시행하는 경우 갑상선 기능 저하증이 유발 되어 평생 갑상선 호르몬제를 복용하여야 하며, 갑상선 부분 절제술을 시행할 경우 갑상선 기능 항진증의 재발 가능성이 있는 것 역시 단점이다.

그레이브스병에 대한 갑상선 절제술의 안정성 및 효용성은 
많이 보고되어 왔지만, 갑상선 절제술의 범위에 대해서는 많 은 논란이 있다. 술 후 갑상선 기능을 유지하기 위해 갑상선 부 분 절제술시 얼마나 많은 양의 갑상선 조직을 남겨야 하는지 에 대해 많은 연구가 이루어지고 있기는 하지만, 아직까지 정 확한 기준은 없다. Palit 등흐은 양측 갑상선 아전절제술을 시행받은 총 4,656예의 그레이브스병 환자를 분석하여, 갑상 선 절제술시 갑상선 잔여량을 조절함으로써 술 후 갑상선 호 르몬의 기능을 조절할 수 있다고 보고하였다. 하지만 갑상선 잔여량과 술 후 갑상선 기능의 변화에 대해 분석한 많은 연구 들에 따르면, 갑상선 부분 절제술시 갑상선 잔여 조직과 정 확한 술 후 갑상선 호르몬 기능 관계를 예측하기는 어렵다고 한다. ${ }^{12,19)}$ 술 후 갑상선 호르몬 기능은 갑상선 잔여량 이외에 도 다른 여러 요인에 의하여 영향을 받기 때문인데, 갑상선 절 제술 후 갑상선 잔여 조직에 혈류의 공급이 적어져서 술 후 갑 상선 기능 저하증이 유발될 가능성이 있고, Hashimoto 병이 동반된 경우에도 술 후 갑상선 기능 저하증이 유발될 가능성이 있다. 술 전 검사상 TSI가 높거나, 갑상선 안구합병증이 동반 된 경우 술 후 갑상선 기능 항진증이 재발될 가능성이 있다. 또 한 갑상선 조직 내의 림프구 침윤이 많을수록 갑상선 자체에 서 갑상선 자극 호르몬 수용체 항체가 생산되어, 갑상선 절제 술 후 같은 잔여량으로도 기능 저하가 잘 생기고, 림프구 침윤 이 없을 경우, 갑상선 이외의 조직에서 자가항체가 생산되므 로, 술 후 기능 항진의 재발 가능성이 많다. ${ }^{19)}$ 본 연구에서는 술 후 갑상선 기능에 영향을 미치는 인자들에 대하여 분석하였 고, 림프구 침윤, TSI, Anti-Tg Ab와 같은 갑상선 자가 항체의 유무와 술 후 갑상선 기능 변화는 통계적인 연관성이 없으나 수술의 범위에 따른 술 후 갑상선 기능은 통계적으로 의미 있는 차이를 보여, 갑상선 아전절제술시 유의하게 전절제술 에 비해 기능 항진의 재발이 많았다. 따라서 술 후 갑상선 호 르몬 기능은 여러 인자들에 의해 복합적으로 조절되기 때문 에, 수술 후에 정확하게 갑상선 기능을 예측하고, 인위적으로 조절하는 것은 매우 어렵다고 사료된다.

그레이브스병의 수술방법에는 크게 갑상선 전절제술, 양측 갑상선 아전절제술, 일측엽 전절제술 및 반대측엽 아전절제 술 등의 세 가지가 있다. 양측 갑상선 아전절제술은 과거부터 가장 보편화된 술식으로 양측에 2 3 gm 정도의 갑상선 잔여 조직을 남김으로써 반회후두신경 마비나 부갑상선 기능저하 증의 발생가능성을 줄이고자 하는 술식이다. 일측엽 전절제 술 및 반대측엽 아전절제술의 장점은 만약의 경우 갑상선 기 능항진증이 재발하여 재수술을 하게 되었을 때 수술 범위가 한쪽에 국한되기 때문에 재수술시 반회후두신경의 마비나 부 갑상선 기능저하의 위험이 감소한다는 이점이 있다. 하지만 두 수술 방법 모두 갑상선을 부분적으로 절제하여 잔여 조직이
남게 되기 때문에 갑상선 기능 항진증의 재발의 가능성이 있다 는 단점이 있다. 한편, 갑상선 전절제술은 술 후 필연적으로 갑상선 기능 저하증이 발생하여 술 후 갑상선 호르몬을 복용 해야 한다는 단점이 있으나 잔여 갑상선 조직이 없기 때문에 갑 상선 기능 항진증의 재발 빈도는 부분적 갑상선 절제술보다 매우 낮다. 본 연구에서도 갑상선 전절제술시 모든 경우에서 갑상선 기능 저하증이 발생하였으며, 술 후 적정량의 갑상선 호 르몬 복용시 모든 경우에서 정상 갑상선 기능을 유지하였고, 갑상선 기능 항진증의 재발은 없었다. 즉, 부분적 절제술과는 달리 갑상선 호르몬제의 조절을 통하여 술 후 갑상선 기능의 조절이 가능하며, 수술 후 가장 치명적인 합병증이 될 수 있는 갑상선 기능 항진증 재발을 막을 수 있다는 장점이 있다.

\section{REFERENCES}

1) Michalek K, Morshed SA, Latif R, Davies TF. TSH receptor autoantibodies. Autoimmun Rev 2009;9(2):113-6.

2) Feliciano DV. Everything you wanted to know about Graves' disease. Am J Surg 1992;164(5):404-11.

3) Weetman AP. The role of surgery in primary hyperthyroidism. J R Soc Med 1998;91 Suppl 33:7-11.

4) Liu J, Bargren A, Schaefer S, Chen H, Sippel RS. Total thyroidectomy: a safe and effective treatment for Graves' disease. J Surg Res 2011;168(1):1-4.

5) Alsanea O, Clark OH. Treatment of Graves' disease: the advantages of surgery. Endocrinol Metab Clin North Am 2000;29(2):321-37.

6) Lee KD, Kim JY, Ha NW, Kim SW, Moon HS, Yun KH, et al. Surgical experience of hyperthyroidisim. Korean J Otolaryngolo-Head Neck Surg 2005;48(8):1027-33.

7) Werga-Kjellman P, Zedenius J, Tallstedt L, Traisk F, Lundell G, Wallin G. Surgical treatment of hyperthyroidism: a ten-year experience. Thyroid 2001;11(2):187-92.

8) Hermann M, Roka R, Richter B, Freissmuth M. Early relapse after operation for Graves' disease: postoperative hormone kinetics and outcome after subtotal, near-total, and total thyroidectomy. Surgery 1998;124(5):894-900.

9) Boostrom S, Richards ML. Total thyroidectomy is the preferred treatment for patients with Graves' disease and a thyroid nodule. Otolaryngol Head Neck Surg 2007;136(2):278-81.

10) Grodski S, Stalberg P, Robinson BG, Delbridge LW. Surgery versus radioiodine therapy as definitive management for graves' disease: the role of patient preference. Thyroid 2007;17(2):157-60.

11) Harada T, Shimaoka K, Arita S, Nakanishi Y. Follow-up evaluation of thyroid function after thyroidectomy for thyrotoxicosis. World J Surg 1984;8(4):436-44.

12) Kasuga Y, Sugenoya A, Kobayashi S, Kaneko G, Masuda H, Fujimori M, et al. Clinical evaluation of the response to surgical treatment of Graves' disease. Surg Gynecol Obstet 1990;170(4):327-30.

13) Abraham $P$, Acharya $S$. Current and emerging treatment options for Graves' hyperthyroidism. Ther Clin Risk Manag 2010;6:29-40.

14) Berglund J, Christensen SB, Dymling JF, Hallengren B. The incidence of recurrence and hypothyroidism following treatment with antithyroid drugs, surgery or radioiodine in all patients with thyrotoxicosis in Malmö during the period 1970-1974. J Intern Med 1991; 229(5):435-42.

15) Barakate MS, Agarwal G, Reeve TS, Barraclough B, Robinson B, Delbridge LW. Total thyroidectomy is now the preferred option for the surgical management of Graves' disease. ANZ J Surg 2002;72 (5):321-4 
16) Palit TK, Miller CC 3rd, Miltenburg DM. The efficacy of thyroidectomy for Graves' disease: a meta-analysis. J Surg Res 2000;90(2): 161-5.

17) Acharya SH, Avenell A, Philip S, Burr J, Bevan JS, Abraham P. Radioiodine therapy (RAI) for Graves' disease (GD) and the effect on ophthalmopathy: a systematic review. Clin Endocrinol (Oxf) 2008; 69(6):943-50.

18) Eckstein AK, Lax H, Lösch C, Glowacka D, Plicht M, Mann K, et al.
Patients with severe Graves' ophthalmopathy have a higher risk of relapsing hyperthyroidism and are unlikely to remain in remission. Clin Endocrinol (Oxf) 2007;67(4):607-12.

19) Reid DJ. Hyperthyroidism and hypothyroidism complicating the treatment of thyrotoxicosis. Br J Surg 1987;74(11):1060-2.

20) Farnell MB, van Heerden JA, McConahey WM, Carpenter HA, Wolff LH Jr. Hypothyroidism after thyroidectomy for Graves' disease. Am J Surg 1981;142(5):535-8. 